DOI: https://doi.org/10.24127/ajpm.v9i2.2714

\title{
EXPLORING THE CREATIVE MATHEMATICAL REASONING OF MATHEMATICS EDUCATION STUDENT THROUGH DISCOVERY LEARNING
}

\author{
Titin Masfingatin $^{1^{*}}$, Wasilatul Murtafiah ${ }^{2}$ \\ ${ }^{1 *, 2}$ Pendidikan Matematika, Universitas PGRI Madiun, Indonesia \\ E-mail: $\quad$ titin.mathedu@unipma.ac.id ${ }^{1 *}$ \\ wasila.mathedu@unipma.ac.id ${ }^{2}$
}

Received 05 March 2020; Received in revised form 21 June 2020; Accepted 28 June 2020

\begin{abstract}
Discovery learning is a learning model that enhancescreative thinking skill including develops students' creative mathematical reasoning. Creative mathematical reasoning process includes novelty, plausibility, and mathematical foundation. This research aims to describe students' creative mathematical reasoning of the mathematics education department on Geometry. The data was collected based on the observation and individual evaluation of students. The results showed that Discovery Learning can (1) grow as much as $35.48 \%$ of students have complete creative mathematical reasoning (novelty, plausibility, and mathematical foundation), (2) grow as much as $64.52 \%$ of students have incomplete creative mathematical reasoning, and (3) grow novelty by $77.42 \%$.
\end{abstract}

Keywords: Creative mathematical reasoning; discovery learning; geometry.

\section{INTRODUCTION}

The 21st century demands students to have life skills and thinking skills. Creative thinking and reasoning skills are essential, especially for Mathematics education students. Along with the demands of times, Mathematics learning, especially in Geometry, requires students to be active in constructing knowledge. Thus students are not only receiving material or knowledge but also actively participating in building theirown knowledge. Example of such learning is the implementation of discovery learning. The implementation of Discovery learning has been proven to provide better mathematics learning outcomes compared to conventional methods(Kistian, Armanto, \& Sudrajat, 2017), and successfully increase geometric learning achievement(In'am \& Hajar, 2017; Ramdhani, Usodo, \& Subanti, 2017). Also, the implementation of discovery learning successfully improves students' creative thinking(Yuliani, Noer, \& Rosidin, 2018).

Discovery learning encourages students' participation in learning activities. Students are directly involved in acquiring material or concepts which foster realistic learning. Furthermore, in the process of concept discovery students are faced with familiar problems and required to solve the problem to understand the concept. The problem-solving process enables students to use their creative thinking skills. Original and creative ideas are needed in order to come up with ideas of problem-solving(Yuliawati \& Panjaitan, 2017).

Geometry is taught during the early semester in the mathematics education program. The level of geometry studied by college students is higher compared to those studied by high school students. For this reason, Students should demonstrate creative thinking as well as 
creative reasoning in order to solve geometry problems with a variety of ideas. Previous studies have shown that students' problem-solving abilities in geometry are still low (Masfingatin, Murtafiah, \& Krisdiana, 2018). Students have not been able to make connections between definitions, postulates, and theorems creatively. Their limited idea in solving geometry problem leads to failure.

Problem-solving and reasoning process are related to one another. To formulate a solution to a certain problem, students must be able to provide a reason. The reasoning is a process of drawing conclusions based on true statements statement or assumed to be true. Students must have the ability to analyze the problem and connect between facts, concepts, definitions, postulates and theory that have been proven before arriving at a conclusion, then linked to previous information to formulate a solution.

Preliminary research shows that students' problem-solving abilities are dominated by algorithmic reasoning(Sukirwan, Darhim, \& Herman, 2018). Algorithmic reasoning is a reasoning process which algorithmically follows only the known patterns. Students will face difficulty if this pattern of problem-solution continues. To this, creative reasoning abilities are needed. Mathematical creative reasoning allows students to solve problems from various points of view and strategies. Creative reasoning is better than algorithmic reasoning, as it will develop students' problemsolving quality.

The problem related to the quality of student reasoning in geometry needs to be seriously addressed. Innovation in learning is needed to develop students' creativity in mathematical reasoning.
Therefore, the researchers intend to apply discovery learning in geometry courses. (Hosnan, 2014) The process of Discovery learning includes: (1) providing stimulus, (2) identifying problems, (3) collecting data, (4) processing data or information, (5) verifying data, and (6) drawing conclusions. The process of discovery learning requires students to actively construct knowledge and linking concepts to find new concepts as the goal of learning.

Discovery learning is categorized as research-based learning shown by the process of learning that students have to conduct(Prahmana, 2015). Researchbased learning has been proven effective in developing the professional competence of Mathematics education students, especially in geometry (Masfingatin, Murtafiah, \& Krisdiana, 2017). The implementation of discovery learning effectively improve reasoning abilities(Safrida., M, \& Hajidin., 2019), stimulate creative thinking, as well as assist students in finding new knowledge or concepts(Jayanto \& Noer, 2013). Also, the result shows that discovery learning effectively improves creative thinking skills(Tumurun, Gusrayani, \& Jayadinata, 2016; Yuliani et al., 2018), which enable the improvement of creative mathematical reasoning.

Several studies on the application of discovery learning in geometry have been conducted (In'am \& Hajar, 2017; Khasanah, Usodo, \& Subanti, 2018; Sahara, Mardiyana, \& Saputro, 2018). Research by Safrida, et al. (2019)also applies discovery learning in mathematics learning. The results of the study indicate that discovery learning can improve students' mathematical reasoning abilities. The mathematical reasoning referred to in the study is 
mathematical reasoning according to Depdiknas (2004), and have not shown any indicators of creative mathematical reasoning. Therefore, researchers conduct research on the exploration of creative mathematical reasoning through the application of discovery learning that has not been revealed in previous studies.

The results of this study can be used as consideration for the selection of learning models in an effort to foster higher quality student reasoning, namely creative mathematical reasoning. The ability of creative reasoning will affect the improvement of student learning outcomes, especially in geometry.

\section{METHODS}

This research is a descriptive study with a qualitative approach.This research was conducted in Universitas PGRI Madiun. The subjects of this research were 1 st-semester students in the mathematics education program consisting of 31 students who were takinga geometry course. This research describes the implementation of discovery learning and the ability of creative mathematical reasoning.

Data were collected through observation, tests, and interviews. The research instrument was an individual test as in Figure 1.

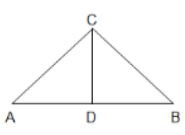

The picture shows that $\triangle A C D \cong$ $\triangle B C D$.

Determine the function of

$\overline{C D}$ in $\triangle A B C$. Explain your reason!

Figure 1. Individual test question.

Observations were conducted while learning was in progress to obtain a picture during the implementation of discovery learning. Individual tests were carried out at the end of learning activities to determine the students' creative reasoning abilities related to geometry.

Research subjects were determined based on answers to individual test results. Individual test results are analyzed and grouped according to creative mathematical reasoning indicators. Each group is chosen by one subject. Furthermore, interviews were conducted on each selected subject.

Interviews of selected subjects were conducted to verify written results and obtain in-depth data related to students' creative mathematical reasoning. Analysis of the data was written and interview conducted with, namely data reduction, data presentation, and drawing conclusion. Testing the validity of the data using triangulation techniques, namely data validity checking techniques by comparing the data from the test results and the results of interviews (Moleong, 2005).

\section{RESULT AND DISCUSSION}

The application of discovery learning in geometry course is implemented, especially on congruent triangle material. Learning activities and creative mathematical reasoning ability of studentsare described as follows.

\section{Implementation of Discovery Learning}

Providing stimulus, which focuses on the discussion of the definition of congruent from two triangles. The process is then followed by discovery activities in which students formed a discussion group consisting of 3-4 members. Each group was given an activity sheet related tothe congruence of triangles. Example ofcongruence problem is two triangles with links in the sides and anglesas well 
DOI: https://doi.org/10.24127/ajpm.v9i2.2714

as propertiesresulting from two congruent triangles. The problem presented is as follows in Figure 2.

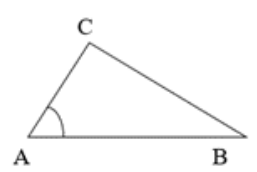

\begin{abstract}
"It is known that the triangle $A B C$ with the length of $A B$ and $A C$ as well as the BAC angle are determined. A PQR triangle is constructed with the length of $P Q$ equal to $A B, A C$ equal to $P R$ and the angle of $R P Q$ is equal to $B A C$. Is the length of the $B C$ the same as the length of the QR?"
\end{abstract}

Figure 2. The problem for group discussion.

Identifying Problem, students observe the problem and identify important information (the known information) from the problem followed by writing important information (the known information) and the problem asked.

Collecting Data, students and groups collect data related to the problem presented. The data can be in the form of definitions, postulates, and theory related to problems.

Processing information, students process the problems, consider the important known information relate to the question and the collected data. Students construct the PQR triangle based on information and provisions from the problem. Students construct the PQ by duplicating $\mathrm{AB}$ and duplicating the $\mathrm{BAC}$ angle to construct the RPQ. The process is then followed by constructing the homework through duplicating the $\mathrm{AC}$ on the $\mathrm{ABC}$ triangle. Finally, connect the points $\mathrm{P}$ and $\mathrm{R}$ to get the PR side of the PQR triangle. Students observe the $\mathrm{ABC}$ and $\mathrm{PQR}$ triangle. The observation should pay close attention to the length of the corresponding sides and the magnitude of the corresponding angles. Observations on the construction show that the $\mathrm{PQR}$ triangle is congruent with the ABC triangle. However, students were not able to conclude the reason for their observation.

Verification, Students construct the triangles repeatedly to ensure that the triangles are always congruent. The analysis results show that the constructed triangles of $\mathrm{ABC}$ and $\mathrm{PQR}$ the same length of sides corresponding to the location. Furthermore, the corresponding angles are also equal. Likewise, the results of the construction of other $\mathrm{ABC}$ triangle. The analysis proves that the $\mathrm{PQR}$ and $\mathrm{ABC}$ triangle is congruent and therefore, in accordance with the definition of congruence.

Drawing conclusions (discoveries), each group concludes that two triangles with two pairs of sides, in which each pair corresponding to each other and the pinched angle of the corresponding pair of sides is congruent, which is then called congruent triangles. Also, based on the definition of congruence of two triangles, all the corresponding parts of the two triangles are congruent. Upon the completion of the discovery process, students in the group conclude the findings.

Furthermore, students were given individual assignments of reasoning tests to discover students' creative mathematical reasoning in connection to the triangle congruence after the application of Discovery Learning. The reasoning test questions are presented in Figure 1.

\section{Creative Mathematical Reasoning Ability of Students}

To discover the students' mathematical creative reasoning abilities, an analysis of the result of the individual test was conducted. The problem that the researcher gave to discover the 
DOI: https://doi.org/10.24127/ajpm.v9i2.2714

students' mathematical reasoning ability(Figure 1) is not challenging enough. However, it is enough to discover students reasoning ability. The problem presented above enables students to use many solutions and categorized an open-ended problem which is in line with (Maharani, 2014), that the appropriate questions to develop students' creative thinking abilities are by giving open-ended questions.

The results of students' individual test were then analyzed based on indicators of creative mathematical reasoning abilities, namely novelty, plausibility and mathematical foundation. The results show the characteristics of student answers as presented in Table 1.

Table 1. Students' creative mathematical reasoning abilities.

\begin{tabular}{clc}
\hline No & \multicolumn{1}{c}{ Point of creative mathematical reasoning } & Number of students \\
\hline 1 & Novelty & $77.42 \%$ \\
\hline 2 & Novelty, Plausibility & $58.06 \%$ \\
\hline 3 & Novelty, Plausibility, Mathematical Foundation & $35.48 \%$ \\
\hline
\end{tabular}

Some of the students' answers were analyzed to describe students' creative mathematical reasoning upon the application of discovery learning in geometry. Each group of students in Table 1 . was taken by one student to be interviewed regarding the ability of creative mathematical reasoning. The results showed that $77.42 \%$ of students were only able to show novelty, indicated by the formation of new reasoning (for students), or the appearance of the long-forgotten reasoning. The following is the example of students' answers related to the criteria for the novelty of KSA and AL students.

Researcher_1: can you explain how do you answer that question?

KSA_1: Based on the picture in the problem, it can be seen that the $C D$ side divides two triangles that are equal in size, also, the $C D$ perpendicular to $A B$, so that the $C D$ is a perpendicular bisector of the triangle $A B C$.

Researcher_2: can you explain the reason for your answer that $C D$ divide $A B C$ intotwo equally triangles?

KSA_2: from the picture, it can be seen that $A C D$ and $B C D$ triangles have the same size. The dimensions of the corresponding sides are the same length".

Researcher_3: How do you know the CD is perpendicular to $A B$ ? Is it known in the problem?

KSA_3: From the image, it can be seen that $C D$ is perpendicular to $A B$

Researcher_4: Other than being perpendicular bisector, does $C D$ have another role?

KSA_4: CD is also an angle bisector because in the figure it is known that the $C D$ divides the $A C B$ angle into two congruent angles

KSA students write more than one answer related to the questions given. However, their answers were not supported by mathematical properties in addition to unable of providing supporting arguments that logically support the answers. They provide more than one possibility of the $\mathrm{CD}$ line function on the problem, namely as a perpendicular bisector and as an angle bisector but fail to provide a logical explanation for the answers. Referring to the results of the student interviews (KSA_1, 2, 3 and 4) which show that there is no logical relationship between the known information and student 
answers, it proves that students' are lack of sequential thinking leading to failure in providing logical explanation (Masfingatin \& Murtafiah, 2017). Their arguments were only based on definitions without referring to the important information presented in the problem. Also, students use the intuitive ability by observing the image to concludeinstead of using mathematical properties. This action shows that students have a semantic understanding based on intuition(Weber \& Alcock, 2004; Tumurun et al., 2016). Thus KSA students only show novelty indicators but do not show plausibility and mathematical foundation.

\section{AL Students}

AL students'answers show novelty and plausibility indicators. They wrotethe known information from the problem; namely, $\triangle \mathrm{ACD} \cong \triangle \mathrm{BCD}$ followed by notting down that $\mathrm{CD}$ side plays three roles, namely as a perpendicular bisector, angle bisector and as a high line. The students wrote the definitions of each bisector perpendicular, bisector angle, and high line in each answer. Although Students were still not able to associate the known information to the possible solution, they were at least able to write the definition. Below shows the thoughtfulness in thinking of $\mathrm{AL}$ students.

Researcher_1: In the problem that you have worked on, explain the steps in the process!

AL_1: First note that the ACD triangle is congruent with the $B C D$ triangle as shown. Based on the image, the $C D$ line functions as perpendicular bisector because $C D$ side divides the $A B$ side into 2 equal lengths, namely the $A D$ and $D B$ sides, and the $A B$ perpendicular to $C D$.
Researcher_2: in your picture, the $A D$ side is not the same as the $D B$, how can you explain that $A D$ is the same as the $D B$ ?

AL_2: I copied it incorrectly, ma'am, the picture in $A D$ should be the same length as $D B$.

Researcher 3: then how can you explain that the $C D$ is perpendicular to $A B$ ? Is it known in the problem?

AL_3: unknown ma'am ... however, if I use a bow to measure it, the two lines form a right angle to each other, so that the two lines are perpendicular to each other.

The above data presents information on students' reasoning ability. Students have been able to mention more than one possible role of $\mathrm{CD}$ line from $\mathrm{ABC}$ triangle. $\mathrm{AL}$ mentionedsome elements that lead to the definition (Figures 2 and AL_1) in addition to being able to show the presence of twists in thinking, andprovide reasoning which lead to conclusions which show their ability in providing logical reasons related to the answers although it was only based on the observation of the image (AL_2), and the measurements result of the image (AL_3). Students used more of their intuition instead of their understanding of mathematical properties, which shows that they still lack creative mathematical reasoning and mathematical foundation.

\section{EM Students}

Analysis of EM Student answers who submit the complete answers. The result of EM's works showsreasoning that fulfills novelty, plausibility, and mathematical foundation.EM students write down the known information followed by some possible roles of the $\mathrm{CD}$ line completed with supporting arguments in two columns, namely statements and reasons. Students analyze the relationship of known information with proven definitions and theorems. In addition to providing 
possible roles of the CD line, they were able to show the logical relationship of information with the definition of two congruent triangles, to which lead to the conclusion of congruence in corresponding sides and the corresponding angles between the two known triangles (ACD and BCD). This finding shows the presence of logical connection in supporting the answers added with mathematical properties (definition, theorem, and mathematical language), which shows creative mathematical reasoning of EM students. (Lithner, 2008).

The application of discovery learning in geometry was able to explore the students' creative mathematical reasoning. Students who showed the development of creative mathematical reasoning were identified at $35.48 \%$.

This information shows
students' creativity on the implementation of discovery learning(Hosnan, 2014), which proven to improve students' ability to think creatively(Yuliani et al., 2018). The stimulus presented requires students to actively construct knowledge, gather information, analyze relationships which lead tothe conclusion of the concept. Independent task which demands many solutions were given task (open-ended)(Daly, Mosyjowski, Oprea, Huang-Saad, \& Seifert, 2016; Maharani, 2014) to foster students' creative thinking. This is in line with(Ramdhani et al., 2017; Yuliani et al., 2018) that the creative questions presented in discovery learning attract students to use their creative thinking to find mathematical concepts through understanding and relating the concept to others.

Creative mathematical reasoning shows the quality of student reasoning that meets the indicators of novelty, plausibility and mathematical foundation(Lithner, 2008). In the application of discovery learning, the most often emerging indicators area novelty, when students can recall the lost reasoning or show new (Handayani, 2013; Lithner, 2008; Olsson, 2017), which was identified when students couldmention some possible answers. Students who demonstrate the ability of novelty can define the concept of the perpendicular bisector, but fail to explain the concept of the angle bisector using mathematical property and more to using their intuition and the results of image observations to form reasoning. This result shows that students have a semantic understanding or effective intuition(Weber \& Alcock, 2004). Through the application of discovery learning students already have an understanding supported by intuition to form answers. This is in line with the results of research(Khasanah et al., 2018)that the process of discovery learning leads students to understand and transfer their knowledge to various contexts to create meaningful learning. Novelty and plausibility were so obvious leaving behind the presence of mathematical foundation. Most of the arguments presented by students were not based on mathematical properties. Instead, Students tend to use intuition in their thinking process to give reason supporting their argument and arriving at conclusion. Although intuition can help students towards logical arguments through their thoughtfulness, it is not mathematically grounded.

Previous research conducted by researchers (still in the process of publishing) is contrary to the results of this study, also the results of the study(Hidayat, Wahyudin, \& Prabawanto, 2018).Previous research 
shows that the novelty indicator is the weakest indicator in students' creative mathematical reasoning, so it requires scaffolding to bring it up. Previous research was conducted before the application of discovery learning in learning geometry, so it is very possible discovery learning is able to bring up novelty indicators in student reasoning. Thus the application of discovery learning is able to foster students' creative mathematical reasoning.

Discovery learning able todevelop complete creative mathematical reasoning as many as $35.48 \%$ of students who show indicators of novelty, plausibility and mathematical foundation. It can also be stated that $64.52 \%$ of students still showed indicators of creative mathematical reasoning that were incomplete. This means that most students do not yet have creative mathematical reasoning. This is in linewith(Birkeland, 2019)that prospective mathematics teacher students have non-imitative reasoning. Non-imitative reasoning includes creative reasoning as well as reasoning that is not creative. In the research mentioned that student reasoning is in the gray zone, namely reasoning that is between imitative (imitating) and creative. In this research we call it incomplete creative mathematical reasoning.

\section{CONCLUSION}

The application of discovery learning is suitable to explore students' creative mathematical reasoning. Approximately $35.48 \%$ of students showed creative mathematical reasoning that fulfills novelty, plausibility and mathematical foundationand $64.52 \%$ students have incomplete creative mathematical reasoning. Novelty is shown when students are able to mention more than one possible answer. This shows that students are able to form new reasoning. Plausibility when students are able to provide logical reasoning that supports answers. Mathematics foundation is shown from the arguments presented based on mathematical properties (definition, theorem and mathematical language). While students with weak reasoning ability tend to use their intuition to solve the problem and make conclusion instead of using mathematical properties. For further research it is recommended to apply discovery learning as an alternative to developing students' creative mathematical reasoning.

\section{REFERENCES}

Birkeland, A. (2019). Pre-service teachers' mathematical reasoning how can it be developed? The Mathematics Enthusiast, 16(1-3), 579-596. Retrieved from https://scholarworks.umt.edu/tme/v ol16/iss $1 / 29$

Daly, S. R., Mosyjowski, E. A., Oprea, S. L., Huang-Saad, A., \& Seifert, C. M. (2016). College students' views of creative process instruction across disciplines. Thinking Skills and Creativity, 22, 1-13.

https://doi.org/10.1016/j.tsc.2016.0 7.002

Handayani, A. D. (2013). Penalaran Kreatif Matematis. Jurnal Pengajaran MIPA, 18(2), 161166.

https://doi.org/http://dx.doi.org/10. 18269/jpmipa.v18i2

Hidayat, W., Wahyudin, \& Prabawanto, S. (2018). Improving students' creative mathematical reasoning ability students through adversity 
DOI: https://doi.org/10.24127/ajpm.v9i2.2714

quotient and argument driven inquiry learning. Journal of Physics: Conference Series, 948(1).

https://doi.org/10.1088/17426596/948/1/012005

Hosnan, M. (2014). Pendekatan Saintifik dan Kontekstual Dalam pembelajaran Abad 21. Jakarta: Ghalia Indah.

In'am, A., \& Hajar, S. (2017). Learning Geometry through Discovery Learning Using a Scientific Approach. International Journal of Instruction, 10(1), 55-70.

Jayanto, I. F., \& Noer, S. H. (2013). Kemampuan Berpikir Kreatif dengan Pembelajaran Guided Discovery. Journal of Contemporary Psychotherapy Schools., 43(2), 73-82. https://doi.org/http://dx.doi.org/10. 1007/s10879-012-9229-1

Khasanah, V. N., Usodo, B., \& Subanti, S. (2018). Guided discovery learning in geometry learning. Journal of Physics: Conference Series, 983(1).

https://doi.org/10.1088/17426596/983/1/012160

Kistian, A., Armanto, P. D., \& Sudrajat, D. A. (2017). The effect of discovery learning method on the math learning of the V SDN 18 students of Banda Aceh, Indonesia. British Journal of Education, 5(11), 226-233.

Lithner, J. (2008). A Research Framework for Creative and Imitative Reasoning. Educational Studies in Mathematics, 67(3), 255-276.

https://doi.org/10.1007/s10649007-9104-2

Maharani, H. R. (2014). Creative Thinking in Mathematics: Are We Able to Solve Mathematical
Problems in a Variety of Way? In International Conference on Mathematics, Science, and Education 2014 (Vol. 2014, p. M 120-M 125).

Masfingatin, T., \& Murtafiah, W. (2017). Identifikasi Berpikir Logis Mahasiswa Tipe Climber dan Quitter Dalam Memecahkan Masalah Geometri. In Prosiding Seminar Nasional Hasil Penelitian (pp. 171-177).

Masfingatin, T., Murtafiah, W., \& Krisdiana, I. (2017). Pembelajaran berbasis riset untuk mengembangkan kompetensi profesional mahasiswa pada mata kuliah geometri. In Prosiding Seminar Hasil Penelitian dan Pengabdian Kepada Masyarakat UNIPMA 2017 (pp. 139-145).

Masfingatin, T., Murtafiah, W., \& Krisdiana, I. (2018). Kemampuan Mahasiswa Calon Guru Matematika dalam Pemecahan Masalah Pembuktian Teorema Geometri. Jurnal Mercumatika: Jurnal Penelitian Matematika Dan Pendidikan Matematika, 2(2), 4150.

https://doi.org/10.26486/jm.v2i2.2 72

Moleong, L. J. (2005). Metodologi Penelitian Kualitatif. Bandung: Remaja Rosda Karya.

Olsson, J. (2017). GeoGebra, enhancing creative mathematical reasoning. Institutionen för tillämpad utbildningsvetenskap. Retrieved from http://www.divaportal.org/smash/get/diva2:108568 7/FULLTEXT01.pdf

Prahmana, R. C. I. (2015). Penelitian Pendidikan Matematika Pembelajaran Berbasis Riset. Yogyakarta: Matematika.

Ramdhani, M. R., Usodo, B., \& 
DOI: https://doi.org/10.24127/ajpm.v9i2.2714

Subanti, S. (2017). Discovery Learning with Scientific Approach on Geometry. Journal of Physics: Conference Series, 895(1). https://doi.org/10.1088/17426596/895/1/012033

Safrida., M, I., \& Hajidin. (2019). The Implementation of Discovery Learning Model to Improve Students , Mathematical Reasoning Skill. International Journal of Sciences: Basic and Applied Research (IJSBAR), 44(2), 19-25.

Sahara, R., Mardiyana, \& Saputro, D. R. S. (2018). Discovery learning with SAVI approach in geometry learning. Journal of Physics: Conference Series, 1013(1). https://doi.org/10.1088/17426596/1013/1/012125

Sukirwan, Darhim, D., \& Herman, T. (2018). Analysis of students' mathematical reasoning. Journal of Physics: Conference Series, 948(1).

https://doi.org/10.1088/1742-

6596/948/1/012036
Tumurun, S. W., Gusrayani, D., \& Jayadinata, A. K. (2016). Pengaruh Model Pembelajaran Discovery Learning Terhadap Keterampilan Berpikir Kreatif Siswa pada Materi Sifat-sifat Cahaya. Jurnal Pena Ilmiah, 1(1), 101-110.

Weber, K., \& Alcock, L. (2004). Semantic and syntactic proof productions. Educational Studies in Mathematics, 56(2-3), 209-234. https://doi.org/10.1023/B:EDUC.0 000040410.57253.a1

Yuliani, T., Noer, S. H., \& Rosidin, U. (2018). Guided Discovery Worksheet for Increasing Mathematical Creative Thinking and Self-Efficacy. International Journal of Trends in Mathematics Education Research, 1(1), 30. https://doi.org/10.33122/ijtmer.v1i 1.6

Yuliawati, N., \& Panjaitan, R. L. (2017). Pengaruh Discovery Learning Terhadap Kemampuan Berpikir Kreatif Siswa Sekolah Dasar. Jurnal Pena Ilmiah, 2(1), 221-230. 